\title{
KAJIAN ILMU KOMUNIKASI PANDANGAN DAN HARAPAN (studi eksploratif tentang pandangan dan harapan pembelajaran IImu Komunikasi pada mahasiswa 5 PTS di DKI Jakarta)
}

\author{
Teguh Priyo Sadono \\ Magister Ilmu Komunikasi, Universitas Bunda Mulia \\ Alamat surel: tsadono@bundamulia.ac.id \\ Rina Nur Chasanah \\ Manajemen, Universitas Bunda Mulia \\ Alamat surel: rchasanah@bundamulia.ac.id
}

\begin{abstract}
Communication Studies in university is a very high study of public interest to learn it, so almost all the universities have faculty and Communication studies program. However, the study of Communication Science is relatively linear and the development of science through verification to test the theory. This fact makes the field of study is not applicable and trapped in the development of knowledge. To avoid the occurrence of cases in the science of Agriculture and Science Administration, which in leave the community then this research is done. This study aims to understand the views and expectations of students semester 7 and above about the study of Communication Science. By using survey method conducted exploration of the object. This research to researched at 320 respondents from 5 PTS in Kopertis III. The results showed that their views on teaching materials Communication Science clearly focused on the development of science. They felt they did not get what they expected with a lecture in Communication Science. Because of that also to equip themselves in the world of work, most want a further study in S2. In conclusion, Communication Science Program is now more to the development of science, less provide applicable provision of communication to students.
\end{abstract}

Keywords: linear, views and expectations

\begin{abstract}
Abstrak
Kajian Ilmu Komunikasi di Perguruan Tinggi merupakan kajian yang sangat tinggi animo masyarakat untuk mempelajarinya, sehingga hampir semua Perguruan Tinggi memiliki Fakultas maupun Program Studi Komunikasi. Namun kajiannya Ilmu Komunikasi relative linier dan pengembangan ilmu melalui verifikasi untuk menguji teori. Kenyataan tersebut menjadikan bidang kajian ini tidak aplikatif dan terjebak dalam pengembangan ilmu. Untuk menghindari terjadinya kasus pada ilmu Pertanian dan Ilmu Administrasi, yang di tinggalkan masyarakat maka penelitaian ini dilakukan. Penelitian ini adalah bertujuan untuk memahami pandangan dan harapan mahasiswa semester 7 ke atas tentang kajian Ilmu Komunikasi. Dengan mengunakan metode survei dilakukan eksplorasi atas obyek penelitian tersebut penelitian ini diteliti pada 320 responden dari 5 PTS di kopertis III. Hasil penelitian menunjukkan bahwa pandangan mereka atas materi ajar Ilmu Komunikasi jelas tertuju pada pengembangan ilmu. Mereka merasa tidak memperoleh apa yg diharapkan dengan kuliah di Ilmu Komunikasi. Karena itu pula untuk membekali diri di dunia kerja, sebagian besar menginginkan studi lanjut di S2. Kesimpulannya Program Studi Ilmu Komunikasi saat ini lebih ke pengembangan ilmu, kurang memberikan bekal aplikatif komunikasi pada mahasiswa.
\end{abstract}

Kata Kunci: Animo, linier, pandangan dan harapan

Jurnal Bricolage Vol. 2 No. 2 


\section{PENDAHULUAN}

\section{Latar belakang}

Perkembangan bidang kajian

Komunikasi di Perguruan Tinggi saat ini sangat pesat. Sejak perubahan bidang kajian dari publisistik ke Ilmu Komunikasi di Tahun 1983 animo masyarakat untuk belajar di bidang kajian Ilmu Komunikasi sangat pesat, sebagai Ilmu Pengetahuan yang tergolong muda. Sekalipun begitu pada sisi yang lain, sejarah perkembangan Komunikasi sudah tua sejak masa Yunani dan baru dirumuskan dalam era modern sebagai Ilmu baru sejak dekade PD II. Dewasa ini penelitian-penelitian Komunikasi terus menerus dilakukan. Berbagai teori Komunikasi bermunculan mulai dari teori-teori klasik yang bersifat linier hingga sirkuler bermunculan. Teori Hypodermic needle Theories, Mechanical Theory, Uses and Gratification Theory, sampai teori-teori sirkuler. Teori efek mulai dari powerful effect hingga limited effect. Kajian-kajian interpretif hingga post modern terus mewarnai kajian-kajian Ilmu Komunikasi hingga Komunikasi menjadi semakin menarik untuk terus didalami.

Demikian pula sejumlah figurnya seperti Paul F. Lazarfeld, Wilbur Schramm, Harold Lasswell, Walter Lippmann, Bernard Berelson, Carl Hovland, Elihu Katz, Daniel Lerner, David K. Berlo, Shannon, Mc Comb, George G. Gebner, dan sebagainya telah dikenal sebagai tokoh-tokoh dalam kajian Ilmu Komunikasi. Termasuk pula pemikir post modern seperti Adorno, Michel Foucaul, dan Derrida.

Di Indonesia, Ilmu Komunikasi yang kita kaji sekarang merupakan hasil dari suatu proses perkembangan yang panjang. Sebelum Ilmu Komunikasi sebagai Program Studi di Tahun 1983, Program Studi ini masih menggunakan nama Publisistik yang masih berorientasi pada pengkajian tentang Pernyataan Umum atau Public care. Beberapa Universitas menempatkan bidang kajian ini dalam bagian dari Ilmu Sosial dan Politik maupun sebagai Fakultas tersendiri seperti di Universitas Padjadjaran Bandung kedudukannya sebagai Fakultas tersendiri dan Universitas Gadjah Mada Yogyakarta, serta Universitas Indonesia sebagai Program Studi dibawah Fakultas Sosial dan Politik. Status Publisistik berubah menjadi Ilmu Komunikasi di Indonesia diperoleh melalui Keputusan Presiden (Keppres) Nomor 107/82 Tahun 1982. Keppres itu yang kemudian membawa penyeragaman nama dari ilmu yang dikembangkan di Indonesia, termasuk Ilmu Komunikasi.

Kajian terhadap Ilmu Komunikasi sendiri dimulai dengan nama Publisistik dengan dibukanya jurusan Publisistik pada Fakultas Sosial dan Politik Universitas Gajah Mada pada tahun 1950, Akademi Penerangan pada tahun 1956, Perguruan Tinggi Publisistik Jakarta pada tahun 1953, dan pada Fakultas Hukum dan Ilmu Pengetahuan Masyarakat Universitas Indonesia pada tahun 1959. Nama Ilmu Komunikasi Massa dan Ilmu Komunikasi sendiri baru muncul dalam berbagai diskusi dan seminar pada awal tahun 1970-an.

Sejak munculnya Keputusan Presiden perkembangan disiplin Ilmu Komunikasi terus menjadi perhatian masyarakat. Animo masyarakat untuk dapat mengkaji Ilmu Komunikasi di Perguruan Tinggi makin meningkat. Hal ini sejalan penerapan Ilmu Komunikasi juga tidak hanya diterapkan internal negara ini saja, melainkan dengan negara-negara lain. Demikian pula usaha untuk menjalin kemitraan global untuk tercapainya cita-cita bersama terus berkembang. Sehingga komunikasi internasional manjadi sangat penting.

Namun demikian perkembangan kajian Komunikasi saat ini menjadi dilematis antara menempatkan komunikasi sebagai kajian dalam rumpun ilmu sosial apakah kajian Komunikasi sebagai ilmu terapan yang lebih menempakan Komunikasi sebagai kemampuan praxis semata. Hal ini terlihat pada perbedaan pandangan tentang kedudukan kajian Komunikasi antra Asosiasi Program Ilmu Komunikasi (ASPIKOM) dengan konsepsi Komunikasi yang di wacanakan oleh Dikti. Bertolak dari pemikiran penempatan kajian Komunikasi sebagai Ilmu Sosial atau Ilmu

Jurnal Bricolage Vol. 2 No. 2 
Terapan. Peneliti ingin memahami pemahaman mahasiswa yang studi Ilmu Komunikasi saat ini tentang persepsi dan harapan mereka tentang kajian komunikasi yang sedang didalaminya.

\section{Perumusan masalah}

a. Bagaimana persepsi mahasiswa Ilmu Komunikasi melihat kajian Komunikasi yang selama ini mereka dalami

b. Bagaimana persepsi mahasiswa tentang materi ajar yang mereka dalami saat ini.

c. Bagaimana harapan mahasiswa tentang bidang studi yang mereka inginkan.

\section{Tujuan penelitian}

a. Untuk memahami persepsi mahasiswa Ilmu Komunikasi DKI Jakarta tetang Ilmu Komunikasi Program Studi

b. Untuk mengetahui harapan mereka tentang bidang kajian

c. Mengetahui persepsi mahasiswa tentang materi ajar di Ilmu Komunikasi

\section{Landasan Pemikiran}

Memahami dilematis tentang
kedudukan kajian Komunikasi mengakibatkan pertanyaan besar tentang eksistensi kajian Komunikasi tersebut. Tentunya eksistensi kajian Komunikasi perlu mendapat perhatian serius untuk menjaga jangan sampai kajian ini seperti kajian Ilmu Administrasi dan Pertanian di beberapa Perguruan Tinggi, yang mengalami kemerosotan baik dalam produk-produk ilmiah maupun animo masyarakat yang ingin mendalami bidang kajian tersebut. Eksistensi bidang kajian di Perguruan Tinggi sangat ditentukan oleh faktor Institusional bidang kajian dan animo masyarakat akan bidang kajian tersebut. Pada era tahun 1980an Fakultas Pertanian dan Fakultas Ilmu Administrasi adalah bidang kajian yang mendapat animo masyarakat dan perhatian besar dari negara untuk dikembangkan, namun tahun 2000-an makin ditinggalkan masyarakat. Penurunan animo masyarakat tersebut selain karena adanya perubahan interest masyarakat di bidang tersebut juga karena faktor struktur sosial.

Kajian Komunikasi di Perguruan Tinggi di Indonesia sudah berlangsung lebih dari setengah abad yang lalu, terus mengalami peningkatan animo dari masyarakat. Secara kuantitas jumlah lembaga pendidikan tinggi Ilmu Komunikasi telah menunjukkan peningkatan yang pesat, dalam massa setengah abad tersebut pendidikan dengan kajian Komunikasi secara kualitas masih perlu banyak perbaikan. Dilihat dari sisi administratif, lembaga tinggi Ilmu Komunikasi tidak saja berada di tingkat Fakultas, namun juga ditingkat Jurusan/Program di bawah Fisip/Fisipol. Bahkan tidak hanya dipelajari di bidang bidang Ilmu Sosial maupun Humaniora, lebih spesifik pada Institut agama-pun dikembangkan. Seperti pada Universitas Islam Negeri (UIN) maupun STAIN juga telah membuka Program Studi Ilmu Komunikasi.

Perkembangan lembaga pendidikan Program Studi Ilmu Komunikasi yang luar biasa tersebut sementara bidang kajian tidak mengalami perubahan dengan siknifikan, dikawatirkan Program Studi ini akan mengalami stagnan, yang kemudian akan mengalami hal sama pada Fakultas Pertanian dan Fakultas Ilmu Administrasi. Apalagi kalau secara struktur tidak ada perubahan yang signifikan dengan perubahan tuntutan kompetensi output Program Studi di masyarakat dan perubahan teknologi. Perubahan struktur kelembagaan dan tata nilai sangat dibutuhkan dalam kajian Ilmu Komunikasi, bidang kajian ini sangat terkait dengan perubahan teknologi komunikasi yang sangat cepat.

Kondisi kelembagaan dan tata nilai pada kajian Ilmu Komunikasi pada umumnya saat ini menghadapi persoalan kualitas pengajaran, mulai dari SDM sampai prasarana penunjang proses belajar mengajar. Hal tersebut menjadi persoalan mendasar dalam menghasilkan lulusan yang kompeten dan berdaya saing tinggi. Di samping itu, kecenderungan lembaga tinggi

Jurnal Bricolage Vol. 2 No. 2 
Ilmu Komunikasi di Indonesia memiliki fokus kajian yang seragam. Hampir semua institusi menyelenggarakan pendidikan Ilmu Komunikasi yang boleh dikatakan kurang lebih sama, yaitu jurnalistik, public relations, periklanan, penyiaran, dan manajemen Komunikasi. Realitas tersebut tentunya sangat mengkhawatirkan kembalinya sindrom Ilmu Pertanian dan Ilmu Administrasi yang dijauhi masyarakat. Untuk itu pelu selalu mengadakan pengamatan kecenderungan perubahan sosial pada masayarakat tentang perubahan kebutuhan tenaga ahli bidang Komunikasi, dan perlunya perubahan pada struktur kelembagaan dan tata nilai yang mengatur bidang kajian Ilmu Komunikasi.

Perubahan struktur orientasi kelembagaan maupun tata nilai akan menggeser arti penting bidang kajian tersebut. Perubahan yang ada dalam sistem sosial dan interest masyarakat tentang bidang kajian tersebut telah memaksa Perguruan Tinggi untuk melakukan penyesuaian-penyesuaian. Namun demikian penyesuaian bidang kajian akan terkendala dengan regulasi yang berubah-ubah. Kondisi demikian mendorong adanya perubahanperubahan rumpun ilmu dan bidang kajian yang baku yang ada dalam bidang kajian. Seperti lahirnya permen (Peraturan Menteri) nomor 154 tahun 2014 tentang rumpun Ilmu Pengetahuan dan Teknologi serta gelar lulusan Perguruan Tinggi, yang mengkategorikan ke dalam 6 rumpun Ilmu serta pengembangan pohon, cabang, atau ranting Ilmu Pengetahuan dan Teknologi dengan strategi: a. monodisiplin; b. multidisiplin; c. interdisiplin; dan d. transdisiplin, telah memberikan ruang pengembangan Program Studi untuk dapat melakukan kajian sesuai dengan tuntutan dan kebutuhan masyarakat.

\section{Perubahan sosial}

Perubahan sosial yang akan menentukan arah Ilmu Komunikasi perlu di pahami secara seksama. Dalam memahami perubahan yang ada dalam masyarakat dapat dipahami dari teori perubahan sosial Dahrendortf tentang hubungan stabilitas struktural sosial dan adanya perubahan sosial dalam masyarakat. Perubahanperubahan yang terjadi dalam struktur kelas sosial akan berakibat pada dua hal yaitu normatif ideologi atau nilai dan faktual institusional. Kepentingan dalam hal ini dapat menjadi nilai serta realitas dalam masyarakat. Artinya ketika struktur sosial berubah maka merubah nilai-nilai dan institusi dalam masyarakat. Sehingga perubahan ynag terjadi dalam masyarakat akan juga mempengaruhi masyarakat dalam menentukan pilihan seiring dengan perubahan nilai yang ada, termasuk pemilihan Program Studi. Dengan demikian gejala perubahan sosial dalam masyarakat dapat dilihat dari terjadinya perubahan sistem nilai maupun norma yang berlaku saat itu dan yang tidak berlaku lagi dalam masyarakat. Tentu saja, perubahan sosial ini terjadi bukan semata-mata karena individu dalam masyarakat tersebut yang mau berubah, akan tetapi karena adanya perkembangan dari berbagai sektor khususnya teknologi. Contohnya saja, budaya konsumtif semakin meningkat dengan ditemukannya ATM dan kartu kredit, dan banyak lagi sistem nilai dan norma yang bergeser dan meninggalkan nilai-nilai yang dulu dianut masyarakat tersebut.

Perubahan teknologi komunikasi yang sangat cepat akan merubah tata nilai yang berlaku dimasyarakat demikian pula perubahan kebutuhan tenaga ahli dibidang komunikasi. Kajian komunikasi tidak lagi hanya melihat dari pemikiran mainstream sebagai proses pengoperan lambanglambang dari komunikator ke komunikan, namun haruslah dilihat dari aspek yang lebih luas. Kajian komunikasi yang relatif seragam pada Program Studi saat ini tentu sangat mengkhawatirkan. Sebab, setiap Perguruan Tinggi Ilmu Komunikasi tidak terlihat ciri khas atau keunggulannya, juga terlalu lambat melakukan perubahan bidang kajian. Kondisi tersebut di samping stagnan juga tidak dapat menunjukkan jati diri atau identitas yang bisa menjadi faktor pembeda dari Perguruan Tinggi lainnya. 
Faktor kesamaan fokus kajian ini kemungkinan selalu berkiblat pada konsepsi pemikiran dan praktik yang terjadi di AS (Amerika Serikat). Di samping itu, pendidikan tinggi Ilmu Komunikasi di Indonesia juga hanya berharap bahwa lulusannya dapat dengan cepat diserap oleh pasar, namun relatif kurang memberi perhatian pada upaya-upaya untuk "menciptakan pasar".

Hal lain karena orientasi lebih banyak ke Amerika berbagai kajian komunikasi yang masih bergelut pada verifikasi menguji kebenaran teori komunikasi dalam paradigm positivistic maupun post positivistic. Kondisi ini mengakibatkan keringnya konseptual yang dibangun oleh kajian komunikasi di Indonesia. Sampai saat ini, belum cukup terlihat upaya para akademisi dan peneliti komunikasi di Indonesia untuk menggali kearifan lokal (local wisdom) guna membangun gagasan-gagasan teoretik komunikasi yang relevan dengan lingkup persoalan yang terjadi di Indonesia.

Bertolak dari landasan berfikir tersebut maka perlu dilakukan ekplorasi opini masyarakat atas Program Studi yang ada dan ekspektasi yang diharapkan pada Program Studi Ilmu Komunikasi. Dengan memahami harapan masyarakat dan penjelajahan Ilmu Komunikasi pada bidangbidang kajian yang akan dikembangkan Program Studi menjadi keterkaitan dalam kontek link and match.

\section{METODOLOGI PENELITIAN}

\section{Tipe Penelitian}

Tipe penelitian ini adalah tipe eksplorasi partikular yaitu tipe penelitian yang bertujuan menggali fakta lapangan realitas atau peristiwa di lapangan untuk dideskripsikan dengan memaparkan secara rinci fakta yang diperoleh dilapangan. Dan melihat kecenderungan yang ada dilapangan.

\section{Metode Penelitian}

Metode yang digunakan dalam penelitian ini adalah metode survei, penelitian survei merupakan penelitian yang mengumpulkan informasi dari suatu sampel dengan menanyakan melalui angket atau interview supaya nantinya menggambarkan berbagai aspek dari populasi (Faenkel dan Wallen, 1990). Survei merupakan salah satu jenis penelitian yang banyak dilakukan oleh peneliti dalam bidang sosiologi, bisnis, politik, pemerintahan dan pendidikan.

\section{Populasi dan sampel}

Populasi penelitian adalah batasan generalisasi yang akan dilakukan dalam penelitian ini, yaitu unit penelitian yang memiliki karakteristik sebagai berikut:

1. Masiswa aktif Ilmu Komunikasi semester 7 ke atas

2. Mereka mahasiswa yang belajar di Perguruan Tinggi di Daerah Khusus Ibu Kota Jakarata.

\section{Ukuran sampel}

Penelitian ini adalah penelitian diskriptif dan bukan penelitian verifikatif, maka ukuran sampel dilakukan dengan quota sampel, dengan sampel sebesar 300 responden.

\section{Teknik Sampling}

Teknik sampling dalam penelitian ini adalah non probability dimana tidak setiap unit penelitian mempunyai hak yang sama menjadi unit analisis. Dan sampling yang dilakukan adalah purposive sampling. Sampel yang dipilih adalah:

1. Mahasiswa Ilmu Komunikasi semester 7 ke atas Universitas Bina Nusanta,

2. Mahasiswa Ilmu Komunikasi semester 7 ke atas London School (LSPR),

3. Mahasiswa Ilmu Komunikasi semester 7 Universitas Bunda Mulia,

4. Mahasiswa Ilmu Komunikasi semester 7 Universitas Mercubuana, dan

5. Mahasiswa Ilmu Komunikasi semester 7 ke atas Universitas Persada Indonesai YAI. 


\section{Sumber data dan tehnik pengambilan data}

Sumber data penelitian ini menggunakan sumber data primer dan sekunder dengan teknik pengambilan data melalui kuesioner yang disebarkan secara porposional pada sampel yang ditentukan.

\section{Analisis Data}

Analisis data menggunakan analisis kuantitatif, statistik diskriptif untuk mengetahui kecenderungan modus dan media dari data terkumpul. Analisis data statistik diskriptif disajikan dalam diagram balok. Dari diskiptif data tersebut kemudian ditafsirkan secara kualitatif untuk memahami kecenderungan kecenderungan unit penelitian.

\section{HASIL PENELITIAN DAN PEMBAHASAN}

Bertolak dari hasil penelitian setelah data terkumpul dan setelah dilakukan proses editing maka data disajikan dalam distribusi data melalui diagram balok.

\section{Distribusi responden}

Responden penelitian ini adalah mahasiswa aktif yang menempuh semester 7 (tujuh) ke atas pada saat penelitian dilakukan. Mereka terdistribusi dalam 5 Perguruan Tinggi Swasa yaitu:

1. Universitas Bina Nusantara.

2. LSPR

3. Universitas Bunda mulia

4. Universitas Mercubuana

5. Universitas Persada Indonesia YAI Total responden 320 orang.

\section{Distribusi Tempat Tinggal responden}

Berdasarkan data terhimpun dilihat dari distribusi tempat tinggal responden tersebut terdisitribusi sebagai berikut:

Tempat Tinggal Responden

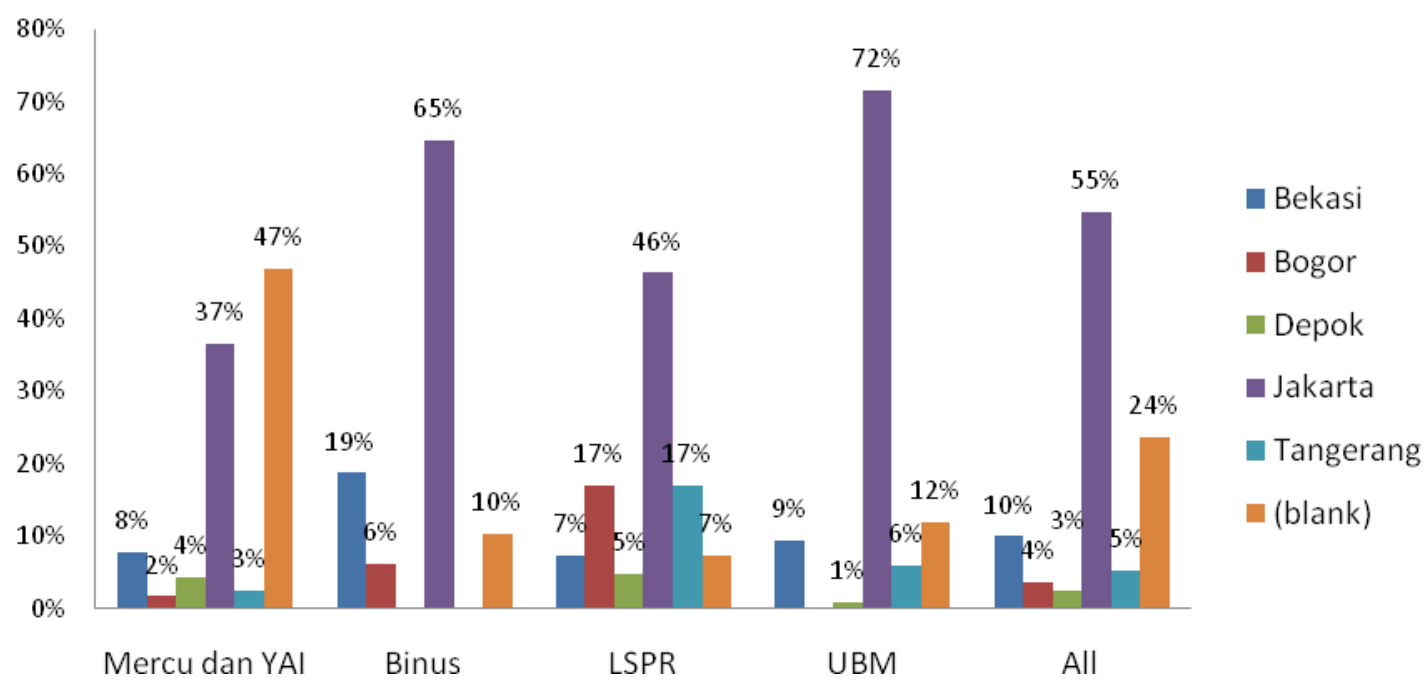

Gambar 1. Tempat tinggal responden

Sumber. Hasil Pengolahan teori, 2016 
Berdasarkan gambar diagram balok tersebut di atas menunjukkan bahwa sebagian besar responden tinggal di Jakarta sebesar $55 \%$, kemudian yang tidak menyebutkan tempat tinggalnya sebesar 24
$\%$ dan sisanya tersebar di Bekasi, Tangerang dan Bogor. Hal ini menunjukkan bahwa ke-5 Perguruan Tinggi di dominasi oleh mahasiswa Jakarta.

\section{Distribusi Jenis Kelamin}

Diagram balok sebaran responden berdasarkan jenis kelamin

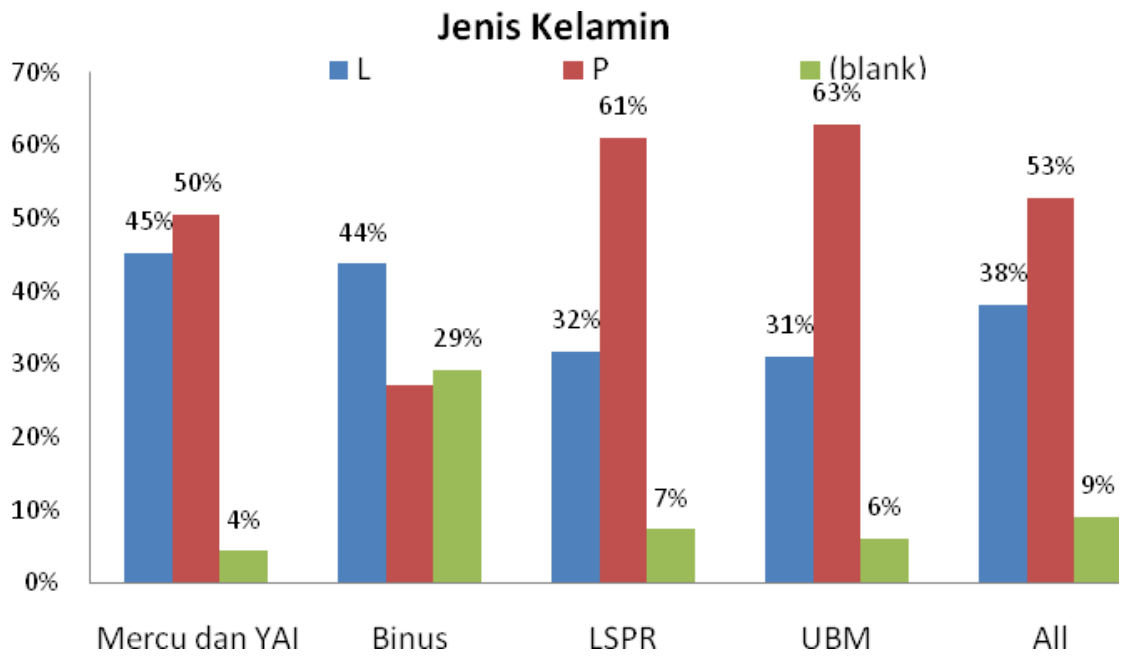

Gambar 2. Jenis kelamin

Sumber. Hasil Pengolahan teori, 2016

Berdasarkan diagram balok tersebut terlihat bahwa jenis kelamin responden relatif terdistribusi merata, artinya data selanjutnya yang diperoleh dalam penelitian ini tidak akan mencerminkan pengaruh dari jenis kelamin dalam memberikan persepsi mereka.

\section{Persepsi responden tentang kurikulum Ilmu Komunikasi}

Kurikulum adalah satuan matakuliah yang dapat memperlihatkan capaian pembelajaran dalam Program Studi. Apabila kurikulum terstruktur dengan jelas maka akan terlihat secara jelas pula capaian pembelajaran tersebut. Pada gambar diagram balok berikut ini menunjukkan persepsi mahasiswa tentang kejelasan arah capaian pembelajaran dalam kurikulum mereka.

Jurnal Bricolage Vol. 2 No. 2 


\section{Keielasan capaian pembelaiaran program studi}

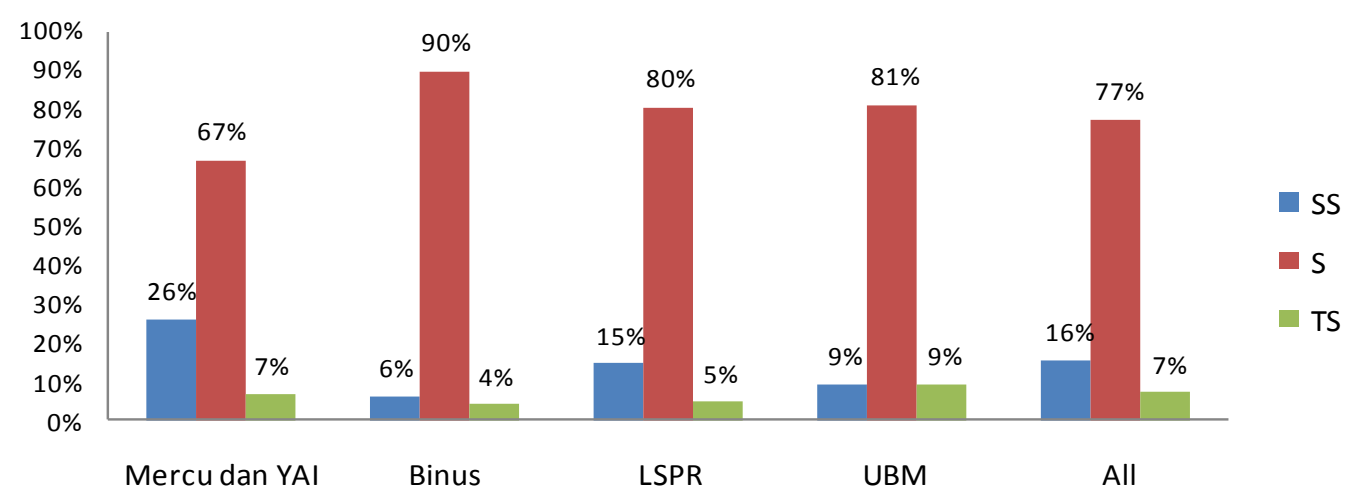

\section{Gambar 3. Kejelasan capaian pembelajaran}

Sumber. Hasil Pengolahan teori, 2016

Diagram tersebut menunjukkan bahwa sebagian besar responden melihat bahwa capaian pembelajaran yang tertuang dalam kurikulum telah secara jelas menunjukkan ketercapaiannya sebanyak 93\% dengan $16 \%$ sangat setuju kalau kurikulum mereka menunjukkan ketercapaian sangat setuju dan $77 \%$ setuju kalau kurikulum mereka menunjukkan secara jelas ketercapaiannya.

Persepsi responden tentang materi ajar

Diagram dibawah menunjukkan tentang persepsi responden mengenai materi ajar di Ilmu Komunikasi yang selama ini mereka pelajari.

\section{Persepsi materi ajar lebih ke arah kajian keilmuan umum}

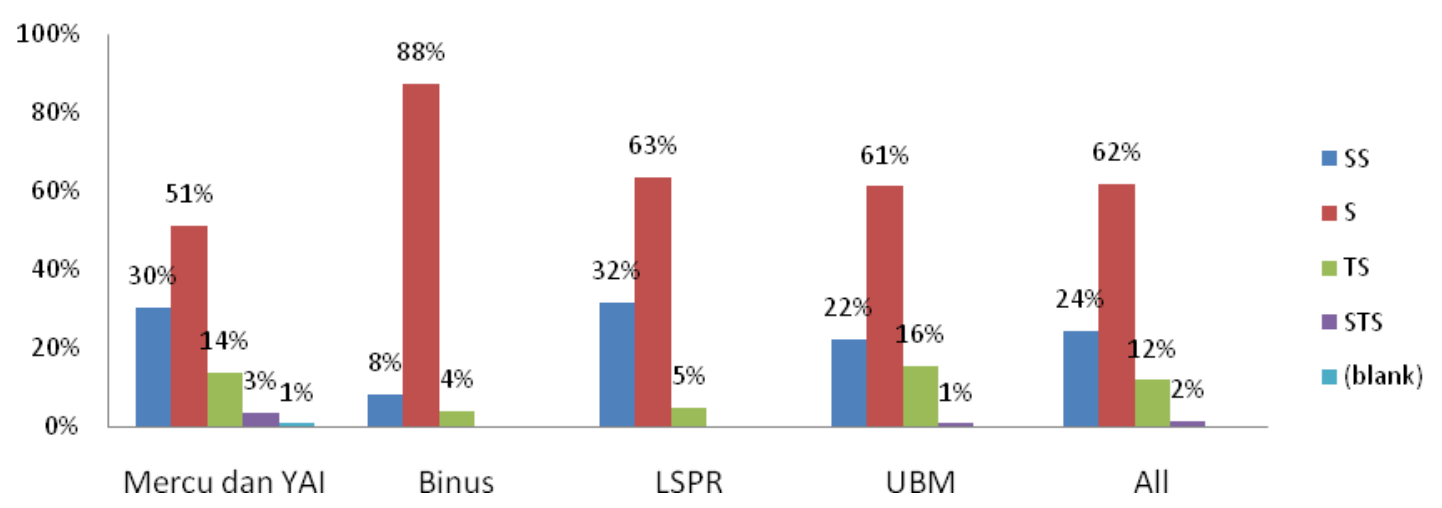

Gambar 4. Arah materi ajar

Sumber. Hasil Pengolahan teori, 2016

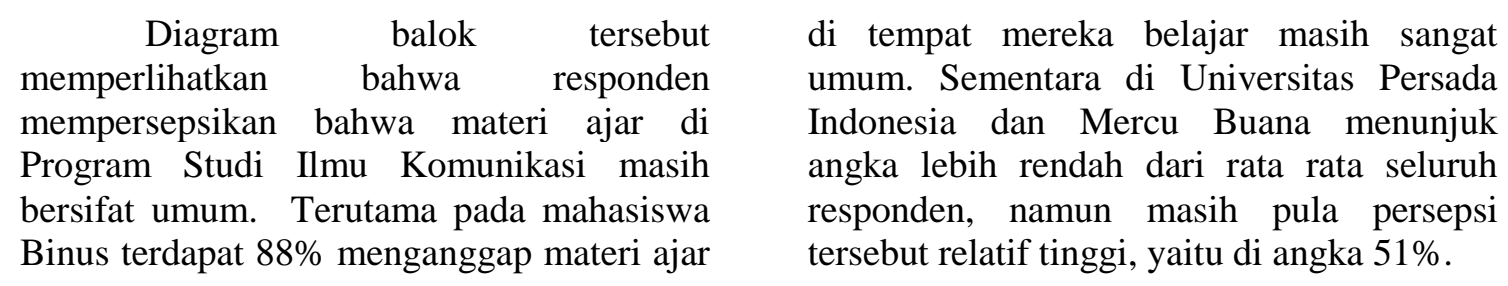


Persepsi responden tentang orientasi pembelajar

Orientasi pembelajaran ini lebih berorientasi pada pembelajaran Ilmu Komunikasi dimana responden belajar.
Eksplorasi ini untuk melihat pandangan responden tentang pembelajaran yang mereka terima selama ini dirasa lebih condong ke keilmuan atau ke bidang keahlian komunikasi.

\section{Orientasi pada pengembangan ilmu komunikasi lebih ke pengembangan ilmu dibanding keahlian komunikasi}

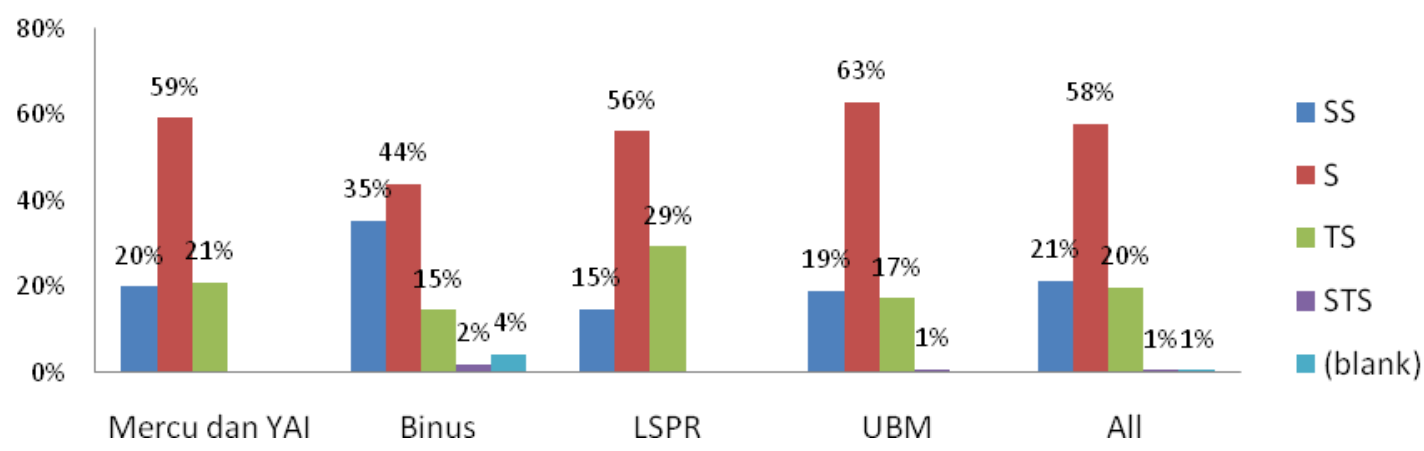

Gambar 5. Persepsi pengembangan bidang ilmu

Sumber. Hasil Pengolahan teori, 2016

Sebaran data tersebut di atas menunjukkan bahwa sebagian besar responden memperlihatkan pernyataan sangat setuju dan setuju bahwa pembelajaran Ilmu Komunikasi lebih banya berorientasi ke bidang keilmuan, yaitu sebesar $78 \%$. Sementara pembelajaran dibidang keahlian komunikasi dirasa masih sangat sedikit.
Perlunya kajian komunikasi lebih kontektual

Kajian Ilmu Komunikasi selama ini masih banyak melihat sebagai kajian yang beorientasi pada keilmuan dan kurang sentuhan bidang keahlian komunikasi. Hal tersebut nampaknya sejalan dengan ekspektasi responden ketika belajar Ilmu Komunikasi. Kajian kontekstual komunikasi lebih diarahkan pada kajian yang dikaitkan pada kepentingan praxis.

Gambar dibawah ini lebih menunjukan kearah mana pembelajaran Ilmu Komunikasi yang diharapkan responden. 


\section{Perlu ada kajian komunikasi yang lebih spesifik pada konteks- konteks tertentu}

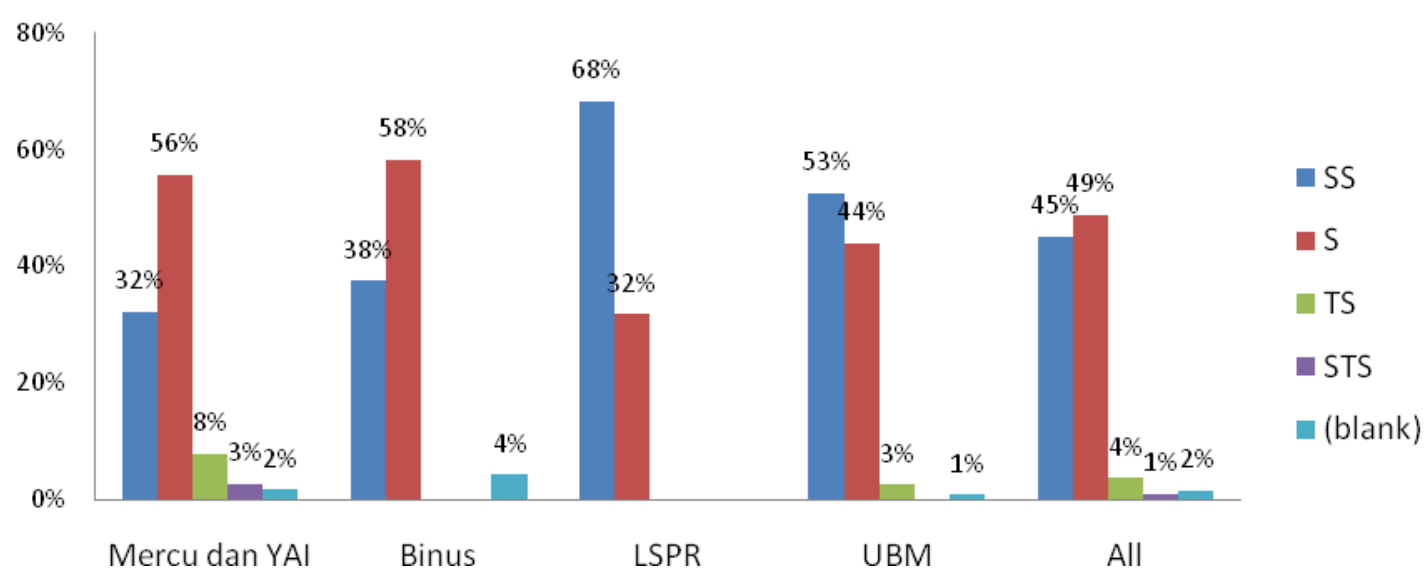

Gambar 6. Spesifikasi konteks-konteks tertentu

Sumber. Hasil Pengolahan teori, 2016

Gambar diagram di atas menunjukkan bahwa sebagian besar responden menginginkan bidang kajian Ilmu Komunikasi lebih diarakan ke arah keahlian komunikasi yang kontekstual, hal ini diperlihatkan 94\% dari 320 responden yang tersebar di 5 Perguruan Tinggi yang diteliti.

\section{Perlunya studi lanjut ke jenjang S2}

Persepsi responden tentang studi yang sedang dijalani hingga semester 7 tersebut apakah masih dirasa kurang untuk membekali mereka dalam dunia kerja? Respon mereka dengan hal tersebut dapat dipaparkan dengan sebaran data tentang kecenderungan perlunya studi lanjut ke jenjang S2, dapat dilihat pada gambar dibawah ini.

\section{Perlu studi lanjut ke Strata S2 supaya mampu bersaing di pasar} kerja

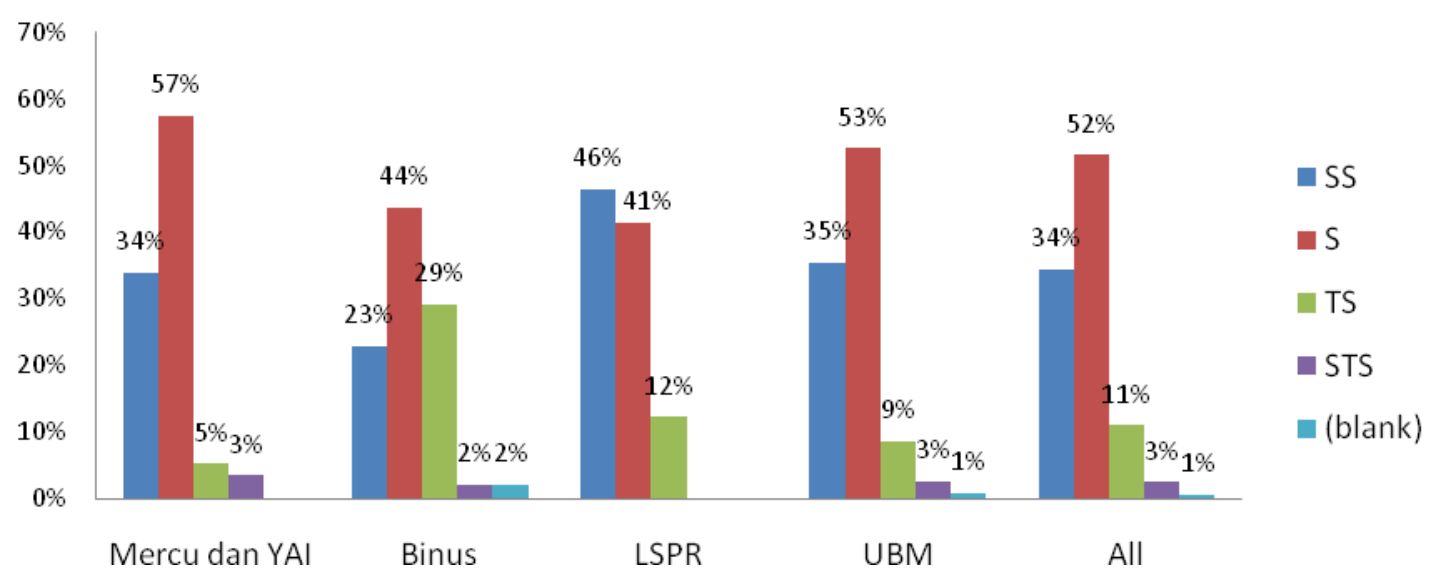

Gambar 7. Perlunya studi lanjut (S2)

Sumber. Hasil Pengolahan teori, 2016 
Sebaran data tentang persepsi responden bahwa perlu adanya studi lanjut di S2 untuk dapat membekali diri di dunia kerja sebesar $86 \%$. Data tersebut menunjukkan betapa besarnya mereka yang studi S1 Komunikasi untuk melaksanakan studi lanjut ke jenjang Strata 2. Keinginan untuk menambah bekal pembelajaran dengan studi lanjut tersebut menunjukkan bahwa mereka merasa adanya tuntutan kompetensi keahlian Ilmu Komunikasi yang meningkat juga kompetisi tenaga Ilmu Komunikasi yang semakin ketat.

\section{PEMBAHASAN}

Meningkatnya animo calon mahasiswa untuk belajar bidang kajian Ilmu Komunikasi akhir-akhir ini nampaknya tidak sejalan dengan harapan mahasiswa Ilmu Komunikasi dengan materi pembelajaran yang diberikan oleh Program Studi kepada mereka. Nampak pada data di atas menunjukkan kecenderungan bahwa harapan mahasiswa untuk memperoleh pengetahuan Ilmu Komunikasi yang implementatif tidak tercermin dalam kurikulum yang ada di Program Studi.

Bertolak dari paparan data tersebut memperlihatkan telah terjadi perubahan orientasi belajar Ilmu Komunikasi pada mahasiswa Perguruan Tinggi Swasta di Jakarta yang lebih prakmatis. Bahwa capaian pembelajaran dalam kurikulum mereka melihat terdapat capaian yang jelas yaitu pada proses pengembangan ilmu pengetahuan. Namun terlihat juga mereka kurang merasa adanya bidang-bidang Ilmu aplikatif. Bahkan terdapat tingginya harapan mereka untuk memahami Ilmu Komunikasi yang lebih kontekstual ke dalam kajiankajian praxis. Hal ini menunjukkan bahwa harapan mereka belajar Ilmu Komunikasi belum terjawab oleh kurikulum yang ada dalam Program Studi Komunikasi. Masih lebarnya jurang pemisah antara harapan mahasiswa dengan materi ajar yang di peroleh didalam kampus.

Harapan untuk memperoleh kompetensi Ilmu Komunikasi yang lebih spesifik pada kepentingan praxis juga sangat menonjol, terlihat dari sebaran data tentang keinginan mereka untuk mendapat materi perkuliahan yang lebih kontekstual. Dari seluruh responden menunjukkan $94 \%$ menunjukan ke arah itu dan hanya $5 \%$ yang merasa sudah cukup dengan materi ajaran yang sekarang mereka jalani. Dan sebaran tersebut hampir merata di ke-5 Perguruan Tinggi yang di survei. Artinya bahwa pendidikan Ilmu Komunikasi yang selama ini diajarkan kurang dapat membentuk kompetensi yang diharapkan mereka.

Kenyataan adanya jarak antara kompetensi yang diajarkan di Program Ilmu Komunikasi dengan harapan mahasiswa di lima Perguruan Tinggi swasta di DKI tersebutlah kemungkinan yang membuat mereka merasa belum siap untuk terjun di dunia kerja. Hasil kajian tersebut menunjukkan pula kemungkinan tersebut sebagai dasar argumentasi mahasiswa untuk berkeinginan melanjutkan studi pada jenjang yang lebih tinggi.

Kecenderungan-kencenderungan di atas ternyata tidak mempunyai relasi dengan identitas responden. Pada jenis kelamin tidak menunjukkan perbedaan akan kecenderungan tersebut, demikian pula dengan lokasi tempat tinggal mereka. Demikian pula perbedaan Perguruan Tinggi dimana mereka belajar juga tidak menunjukkan kecenderungan membedakan kecenderungan persepsi mahasiswa tentang Program Studi Ilmu Komunikasi. Hal ini menunjukkan hampir dipastikan bahwa kompetensi yang dituangkan dalam materi ajar di Program Studi Ilmu Komunikasi belum mampu memenuhi harapan dari mahasiswanya.

\section{KESIMPULAN}

Dengan meningkatnya animo masyarakat yang menuntut ilmu di Program Studi Ilmu Komunikasi di satu sisi memberikan harapan semakin banyaknya orang terpacu untuk meningkatkan kesadaran akan informasi well informed, di sisi lain menuntut institusi penyelenggara Program Studi Ilmu Komunikasi untuk dapat mengarahkan mereka pada pembentukan 
manusia yang sadar akan informasi dan komunikasi.

Namun demikian hasil penelitian ini menunjukkan arah yang bertentangan antara harapan dengan apa yang diberikan. Hal ini menunjukkan bahwa Program Studi Ilmu Komunikasi di 5 Perguruan Tinggi tersebut belum mampu mengubah kurikulum sesuai dengan perubahan tuntutan mahasiwa dan dunia kerja di bidang Ilmu Komunikasi. Kenyataan semacam ini kalau tidak segera diatasi maka akan terjadi pengulangan berupa penurunan drastis seperti pada Program Studi Ilmu Administrasi dan Pertanian. Untuk itu Ilmu Komunikasi harus berani keluar dari kajian monodisiplinen ke kajian-kajian multi, inter atau trans disipliner.

\section{DAFTAR PUSTAKA}

Emmert, Philip; Larry L. Barker. Meansurement of Communication Behavior; Logman Inc; London, 1989.

Fraenkel, J. R., Wallen, N. E., \& Hyun, H. H. How to design and evaluate research in education (8th ed.). McGraw-Hill. New York: 2012.

Hardiman, F. Budi, Menuju masyarakat Komunikatif. Penerbit Kanisius, Yogyakarta 1993.

Littlejohn, Stephen W; Kare A. Foss; Teori Komunikasi (terjemahan); edisi 9; Penerbit Salemba Humanika, Jakarta, 2009. 